\title{
Bushmeat consumption in large urban centres in West Africa
}

\author{
Luca Luiseli, Emmanuel M. Hema, Gabriel Hoinsoudé Segniagbeto \\ Valy Ouattara, Edem A. Eniang, Gnoumou Parfait, Godfrey C. Akani \\ Djidama Sirima, Barineme B. Fakae, Daniele Dendi and Julia E. Fa
}

\begin{abstract}
There is an unprecedented demand for bushmeat in large cities in sub-Saharan Africa, and this is a major threat to many species. We conducted 2,040 interviews in six cities in four West African countries, in forest and savannah settings. We analysed age- and sex-related differences in the frequency of bushmeat consumption. Overall, we found similar patterns in all cities: $62.2 \%$ of men and $72.1 \%$ of women said they would never eat bushmeat, whereas $12.8 \%$ of men and $8.8 \%$ of women said they liked bushmeat and ate it regularly. Younger generations of both sexes tended not to eat bushmeat, regardless of their city of origin. This study of the effects of age, gender and geographical location on bushmeat consumption in African cities provides insights regarding which population groups to target in campaigns to change behaviours.
\end{abstract}

Keywords Age, Burkina Faso, gender, geographical location, Niger, Nigeria, Togo, wild meat

$\mathrm{T}$ he urban population in sub-Saharan Africa is projected to double to c. 1.1 billion by 2050 as a result of rural to urban immigration, and $>80 \%$ of that increase will occur in West African cities (World Bank, 2016). This urbanization

LuCA Luiselli* (Corresponding author) and Daniele Dendi Institute for Development, Ecology, Conservation and Cooperation, via G. Tomasi di Lampedusa 33, I-00144 Rome, Italy

E-mail 1.luiselli@ideccngo.org (D) https://orcid.org/0000-0001-6878-2916

Emmanuel M. Hema, Gnomou Parfait and Diddama Sirima Laboratoire de Biologie et Ecologie Animales, Université Ouaga 1 Professeur Joseph KiZerbo, Ouagadougou, Burkina Faso

Gabriel Hoinsoudé Segniagbeto Department de Zoologie, Faculté des Sciences, Université de Lomé, Lomé, Togo

Valy OuatTara Groupe des Expert en Gestion des Eléphants et de la Biodiversité de l'Afrique, de l'Ouest, Ouagadougou, Burkina Faso

EdEm A. EnIANg Department of Forestry and Wildlife, University of Uyo, AkwaIbom State, Nigeria

Godfrey C. Akani and Barineme B. Fakae Department of Applied and Environmental Biology, Rivers State University of Science and Technology, Port Harcourt, Nigeria

Julia E. FA Division of Biology and Conservation Ecology, School of Science and the Environment, Manchester Metropolitan University, UK, and Center for International Forestry Research, Bogor, Indonesia

*Also at: Department of Applied and Environmental Biology, Rivers State University of Science and Technology, Port Harcourt, Nigeria

Received 18 May 2018. Revision requested 12 June 2018.

Accepted 18 June 2018. First published online 11 December 2018.

Article updated on 12 August 2022 may have positive effects in driving the economic development of the continent but may also cause unprecedented environmental damage (Oates et al., 2004).

The population increase in cities places greater demands on natural resources, especially food. Bushmeat, or the meat of wild animals, is a crucial source of protein for rural people and is also consumed by urban inhabitants, often as a commodity ( $F a$ et al., 2002a,b, 2006; Brashares et al., 2011). Although bushmeat may be less important for the food security of large cities (Hema et al., 2017; Luiselli et al., 2017a,b), the overall volume consumed can be large and this can have consequences for the targeted wildlife populations (van Vliet et al., 2011). To guide behaviour-change campaigns there is a need to ascertain which consumer groups should be targeted, and whether this varies by geographical location. Here we analyse the responses of $>2$, 000 interviewees from six large urban centres (all with $>500,000$ inhabitants) in four West African countries, and highlight similarities and differences between them.

During 2012-2017 we conducted face-to-face interviews, using a standardized questionnaire, with 2,040 people in Nigeria (Port Harcourt, $n=422$ and Calabar, $n=452$ ), Togo (Lomé, $n=264$ ), Burkina Faso (Ouagadougou, $n=262$ ), Côte d'Ivoire (Abidjan, $\mathrm{n}=368$ ) and Niger (Niamey, $\mathrm{n}=272$ ) (Fig. 1). African scientists and students amongst the authors conducted all interviews in the appropriate local language. Interviewees were selected randomly at marketplaces, canteens, restaurants, roadsides, hairdressing salons, food shops and other gathering places. This involved stopping the first adult (we did not interview minors) met after a given time period (in minutes), with the time interval generated by a random number generator. Interviewees were informed of the aims of the project and then asked for their verbal consent before proceeding. The identity of interviewees was kept anonymous to ensure privacy (St. John, 2010; Nuno \& John, 2015).

In each interview we recorded the gender (male or female) and age (18-25, 26-50, $\geq 51$ years) of the interviewee. To avoid interdependence of the data, we did not question multiple members of the same family, or people living in the same house, even if they were not related (Hema et al., 2017).

We asked the following questions: Do you like eating bushmeat? If yes, how often do you eat bushmeat? If not, do you eat it on occasion nevertheless? We also asked about reasons for consuming (e.g. because bushmeat is a 


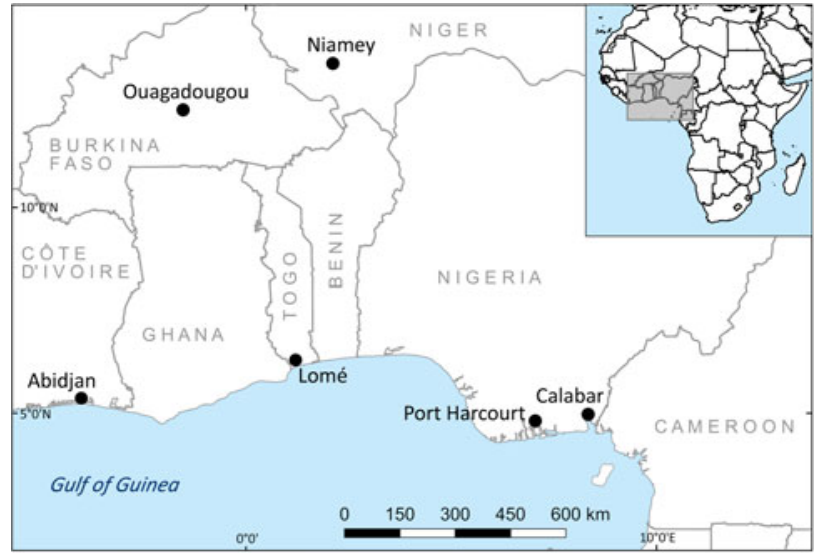

FIG. 1 Locations of the six cities in West Africa where interviews were conducted to investigate bushmeat consumption.

cheaper alternative) or not consuming bushmeat. Interviewees were then asked if they ate bushmeat regularly (normally at least once per week, but at least 2-3 times per month), occasionally (c. once per month or less often) or never. Interviewees who answered that they consumed bushmeat only occasionally were then asked whether they chose the type of animal, or whether their choice was based on which species were available, or on the price compared to domestic meat.

Although we informed all interviewees that our study was not linked to any government department, we acknowledge that some level of misrepresentation may have occurred because of fear of repercussions, as the bushmeat trade is illegal in some areas (e.g. Burkina Faso; Hema et al., 2017).

To compare frequency differences among respondents who often, rarely or never ate bushmeat we used a $\chi^{2}$ test. We used PASW 11.o (IBM, Armonk, USA) for all statistical analyses, with $\alpha=0.05$.

Across all six cities a mean of $62.2 \pm \mathrm{SD} 26.2 \%$ of men and $72.1 \pm$ SD $22.1 \%$ of women answered they would never eat bushmeat $\left(\chi^{2}=0.10, \mathrm{df}=5, \mathrm{P}=0.999\right)$, and $12.8 \pm \mathrm{SD} 8 \%$ of men and $8.8 \pm$ SD $1.7 \%$ of women said they liked bushmeat and ate it regularly $\left(\chi^{2}=0.17, \mathrm{df}=5, \mathrm{P}=0.998\right)$. There were no significant differences in the proportions of interviewees who said they ate bushmeat only rarely $\left(\chi^{2}=7.79, \mathrm{df}=5\right.$, $\mathrm{P}=0.169$ ).

Between cities there was a significant difference in the frequency of men indicating they never eat bushmeat $\left(\chi^{2}=29.13\right.$, $\mathrm{df}=5, \mathrm{P}<0.001$ ), with fewer men in Ouagadougou and Lomé stating they never eat bushmeat (Fig. 2). The frequency of women indicating they never eat bushmeat also varied significantly between cities $\left(\chi^{2}=27.4, \mathrm{df}=5, \mathrm{P}<0.001\right)$, with a similar pattern in Ouagadougou and Lomé as for men.

The frequency of both men and women declaring they rarely eat bushmeat varied significantly between cities $\left(\chi^{2}=24.2, \mathrm{df}=5, \mathrm{P}<0.0001\right.$ and $\chi^{2}=23.7, \mathrm{P}<0.001$, respectively), with Ouagadougou differing in that more

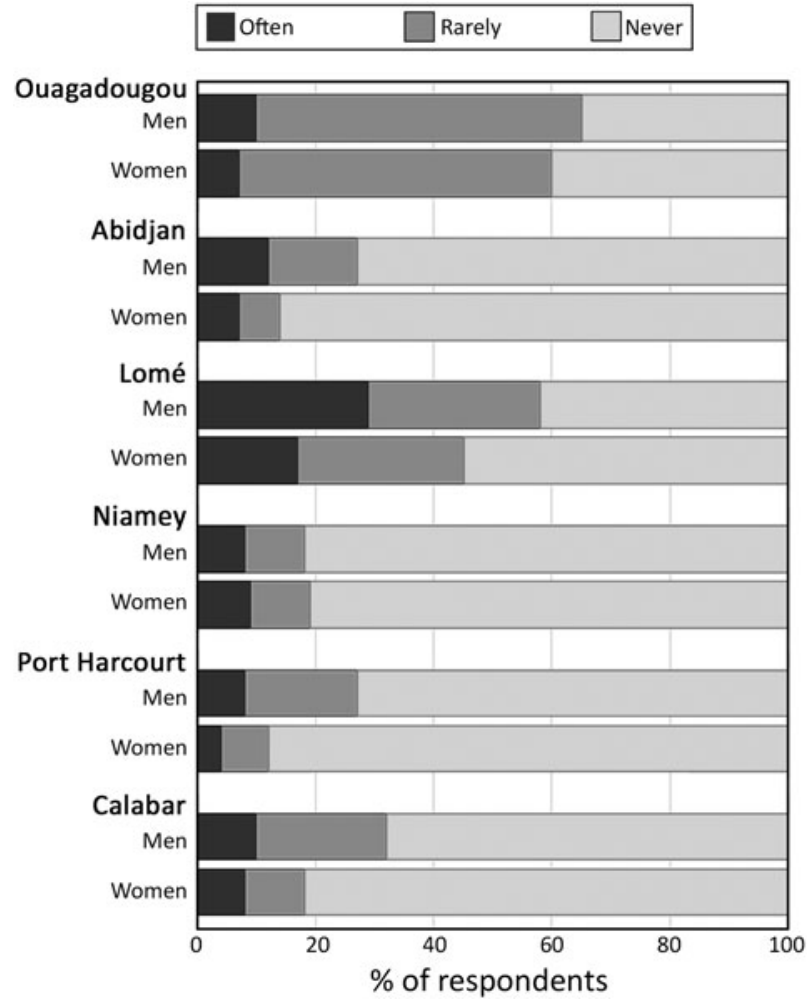

Fig. 2 Per cent of men and women interviewed in each of the six study cities (Fig. 1) who said they ate bushmeat often, rarely, or never.

people than expected answered this question positively (Fig. 2).

The proportion of men declaring they eat bushmeat frequently varied significantly between cities $\left(\chi^{2}=25.4, \mathrm{df}=5\right.$, $\mathrm{P}<0.0001$ ), with a higher proportion in Lomé (Fig. 2). The proportion of women declaring they eat bushmeat frequently did not differ significantly between cities $\left(\chi^{2}=10.1\right.$, $\mathrm{df}=5, \mathrm{P}=0.068$ ). The least consumption of bushmeat was amongst younger interviewees, independent of city and gen$\operatorname{der}\left(\chi^{2}\right.$ test, $\mathrm{P}>0.500$; Fig. 3$)$.

Of the 620 people who responded to the question 'why do you eat wild meat regularly?', 433 said it was because they liked the taste, 141 because of its availability, and 162 consumed it only during traditional events. Of those declaring that they don't eat bushmeat $(n=1,420), 933$ said they did not like the taste, 196 said it was difficult to find and 764 had health concerns. Several people gave multiple reasons, and therefore the subtotals sum to more than the total.

As far as we are aware, our study is the first to examine bushmeat consumption patterns in large cities in West Africa. Given the large sample size, we are confident that the patterns emerging are representative and, given the simplicity of our questions, we consider that significant bias is unlikely. As all interviews were administered by nationals and in their own language, false interpretations of the questions are also unlikely. However, certain 


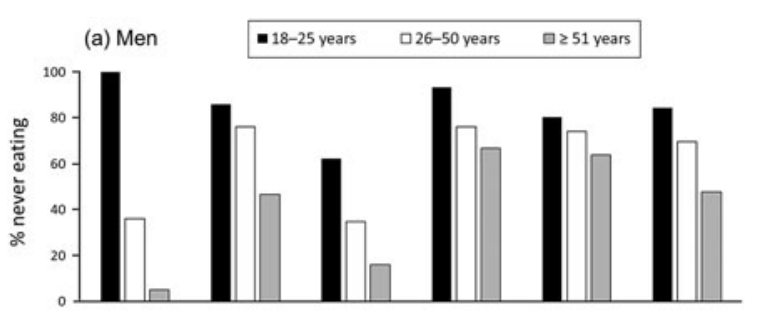

(b) Women

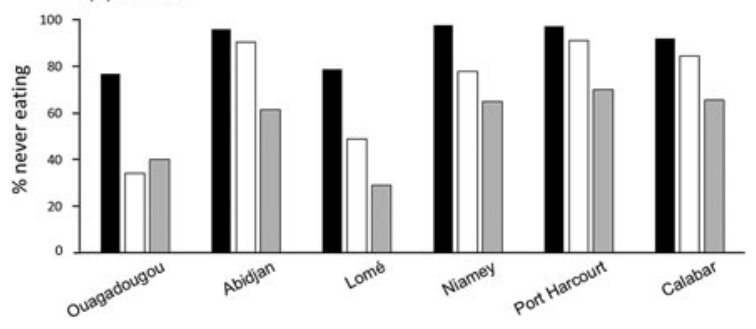

FIG. 3 Age-distribution of (a) male and (b) female respondents who said they never eat bushmeat for each of the six study cities (Fig. 1). More younger than older people, irrespective of their city of origin, stated that they never eat bushmeat.

demographic groups were under-represented in our study in some cities (e.g. Ouagadougou, where only seven men aged 18-25 years were interviewed), and this may have partially affected our findings.

Three clear results arise from our surveys: (1) c. $30 \%$ of people ate bushmeat, but many of them only occasionally, (2) there were no difference between sexes, and (3) younger cohorts of both sexes tended to avoid consuming bushmeat. We also found differences in bushmeat consumption between cities and rural areas (Luiselli et al., 2017a,b).

The fact that younger men and women were less likely to eat bushmeat compared to the older groups is an important finding that may indicate a shift in eating patterns away from more traditional foods. This trend may indicate a nutritional transition in sub-Saharan populations that are modernizing as a result of increased socio-economic development associated with urbanization and acculturation (Vorster et al., 2011). Informal observations of young interviewees who stated they never ate bushmeat revealed that their dress was non-traditional (they wore western-style clothes), they frequented clubs and discotheques, used social media and smartphones, often possessed a personal computer, watched pay-per-view television channels, and routinely consumed fast food (hamburgers, shawarma, pizza). Thus they may consider some cultural attributes (such as bushmeat consumption) to be unfashionable.

Bushmeat supply to urban markets and the impact of the Ebola crisis (Akani et al., 2015a; Ordaz-Németh et al., 2017) may have been important factors determining bushmeat consumption. In Ouagadougou, for example, the lack of bushmeat consumption could be related to the illegality of the bushmeat trade, and also to the fact that the source areas (mostly protected areas and adjacent buffer zones) are at a considerable distance from the city (Hema et al., 2017). In Nigeria, where bushmeat markets are open, and usually close to the main urban centres (e.g. the Oigbo and Omagwa markets for the Port Harcourt metropolitan area), social factors may be more important (Akani et al., 2015b).

We predict that, with the ongoing expansion of cities in West Africa, progressively fewer people will consume bushmeat on a regular basis. The potential implications of this development on species conservation merits long-term study.

Acknowledgements This study was funded by the Mohamed bin Zayed Species Conservation Fund, Conservation International, the Turtle Conservation Fund, Andrew Sabin \& Family Foundation, T.S. K.J. Nigeria Ltd, IUCN/Species Survival Commission Tortoise and Freshwater Turtle Specialist Group, Aquater S.p.A. and Snamprogetti S.p.A.

Author contributions Study design: LL, BBF, JEF; fieldwork: all authors; data analysis and writing: LL, JEF.

\section{Conflicts of interest None.}

Ethical standards This research complied with the ethical guidelines developed by the British Sociological Association and the Code of Conduct for Oryx authors.

\section{References}

Akani, G.C., Dendi, D. \& Luiselli, L. (2015a) Ebola virus effects on the bushmeat trade in West Africa. African Journal of Ecology, 53, $613-615$.

Akani, G.C., Amadi, N., Eniang, E.A., Luiselli, L. \& Petrozzi, F. (2015b) Are mammal communities occurring at a regional scale reliably represented in "hub" bushmeat markets? A case study with Bayelsa State (Niger Delta, Nigeria). Folia Zoologica, 64, 79-86.

Brashares, J.S., Golden, C.D., Weinbaum, K.Z., Barrett, C.B. \& OKELLO, G.V. (2011) Economic and geographic drivers of wildlife consumption in rural Africa. Proceedings of the National Academy of Sciences of the United States of America, 108, 13931-13936.

FA, J.E., Peres, C.A. \& Meeuwig, J. (2002a) Bushmeat exploitation in tropical forests: an intercontinental comparison. Conservation Biology, 16, 232-237.

FA, J.E., Juste, J., Burn, R.W. \& Broad, G. (2002b) Bushmeat consumption and preferences of two ethnic groups in Bioko Island, West Africa. Human Ecology, 30, 397-416.

Fa, J.E., Seymour, S., Dupain, J., Amin, R., Albrechtsen, L. \& Macdonald, D. (2006) Getting to grips with the magnitude of exploitation: bushmeat in the Cross-Sanaga rivers region, Nigeria and Cameroon. Biological Conservation, 129, 497-510.

Hema, E.M., Ouattara, V., Parfait, G., Di Vittorio, M., Sirima, D., Dendi, D. et al. (2017) Bushmeat consumption in the West African Sahel of Burkina Faso, and the decline of some consumed species. Oryx, published online 10 April 2017.

Luiselli, L., Hema, E.M., Segniagbeto, G.H., Ouattara, V., Eniang, E.A., Di Vittorio, M. et al. (2017a) Understanding the influence of non-wealth factors in determining bushmeat consumption: results from four West African countries. Acta Oecologica, published online 16 october 2017. 
Luiselli, L., Petrozzi, F., Akani, G.C., Di Vittorio, M., Amadi, N., Ebere, N. et al. (2017b) Rehashing bushmeat - interview campaigns reveal some controversial issues about the bushmeat trade dynamics in Nigeria. Revue d' Ecologie (Terre et Vie), 72, 3-18.

Nuno, A., \& John, F.A.S. (2015) How to ask sensitive questions in conservation: A review of specialized questioning techniques. Biological Conservation, 189, 5-15.

OAtes, J.F., Bergl, R.A. \& Linder, J.M. (2004) Africa's Gulf of Guinea forests: biodiversity patterns and conservation priorities. Advances in Applied Biodiversity Science, 6, 1-91.

Ordaz-Németh, I., Arandjelovic, M., Boesch, L., Gatiso, T., Grimes, T., Kuehl, H.S. et al. (2017) The socio-economic drivers of bushmeat consumption during the West African Ebola crisis. PLOS Neglected Tropical Diseases, 11, eooo5450.

van Vliet, N., Nasi, R. \& Taber, A. (2011) From the forest to the stomach: bushmeat consumption: from rural to urban settings in Central Africa. In Non-Timber Forest Products in the Global Context (eds S. Shackleton, C. Shackleton and P. Shanley), pp. 129-148. Springer-Verlag, Berlin, Heidelberg, Germany.

Vorster, H.H., Kruger, A. \& Margetts, B.M. (2011) The nutrition transition in Africa: can it be steered into a more positive direction? Nutrients, 3, 429-441.

WORLD BANK (2016) Statistics: Countries and Economies. World Bank, New York, USA. 